\title{
HOPELESSNESS IN J. C. DAWN'S SELECTED POEMS
}

\author{
Cindi Novita, Pramudana Ihsan, Ari Setyorini \\ Universitas Muhammadiyah Surabaya, Surabaya, Indonesia. \\ E-mail: cindinov875@gmail.com
}

Received: 2021-06-07

Accepted: 2021-06-16

\begin{abstract}
This research examines the hopelessness described in the poems by J. C. Dawn entitled Living in A Pride World, Womb, and A Soundless Tear in her book The Ripple of Existence. This research is a descriptive qualitative study that aims to describe the words used to express hopelessness. The method used to analyze the poems is the analysis of intrinsic elements in poetry with a psychological approach to find out about hopelessness experienced by the characters in each poem. Hopelessness is a condition experienced by anyone where where there is no more hope. This would also be contextualized in real life concerning the stages of someone experiencing hopelessness based on Abramson's theory. The results of the research show that the "I" character in the first poem experiences a failure in himself; in the second poem, "I" faces struggles under challenging conditions and in the third, "she" finds herself unable to accept the reality of life.
\end{abstract}

Keywords: hopelessness, poem, psychological, intrinsic elements

\section{Introduction}

Hopelessness is the loss of interest in reinforcing a particular thing where there will be an expectation that the desired outcome will not occur or that the unwanted will occur. The person concerned is unable to respond to change the situation (Abramson et al., 1989). The initial feeling of helplessness that lingers can also lead to hopelessness, usually associated with grief, frustration, and suicidal thoughts. A state of hopelessness is one of the disorders that cause ongoing depression, becoming a complex condition. The relationship between hopelessness is also a mediator to anxiety in a depressed state (Chu et al., 2018). The researchers of psychology have long suggested that depression is not a single disorder but a heterogeneous group of disorders concerning symptoms, causes, reasons, therapy, and prevention (Beck, 1967). Everyone has experienced hopelessness in his life, considering that hopeless conditions can be experienced by anyone and come from various age segments and various backgrounds. It occurs in many forms and is a feeling that is felt more often and more commonly felt than spoken.

Psychological influence greatly determines how a person responds to a condition of hopelessness in various ways. People can now find themselves feeling hopeless through literary works with the negative side of life, hopelessness. The ability of poetry can represent whatever feelings are felt (Saputra, 2011). The psychological and legal types in literary works ultimately affect the readers who have a powerful influence (Aras, 2015). They can create relationships between artists and connoisseurs through novels, poetry, paintings, sculptures, etc. Some can position themselves to be positive, but some people show negative attitudes after knowing the writing that suits their situation. 
Literature is the art of creating. Like other works of art, the creator expresses his thoughts on his work. Because the nature of literature is language and language is a means of communication, literature is also considered an instrument used to express the creator's feelings, ideas, or attitudes towards everything (Minderop, 2010). The topic of death has long been described in literary works. The author uses novels, fiction, or short stories as instruments to convey his ideas towards death. The topic of death has also been discussed many times in poetry. Poetry is known as the most personal literary work. Poetry expresses more experiences and feelings through the use of metaphors in poetry (Rahman, 2021). Poets only select a few words representing their thoughts, and readers use their own experiences and personal knowledge to understand the meaning of the poem. This makes each reader will have a different interpretation even of the same poetry.

Furthermore, literary work on social media platforms is easily accessible to everyone. Its users can use social media that is developing in society due to technological developments. In this case, the link between literature and social media plays an essential role in channeling the author's ideology to society (Rahmi et al., 2017). Of course, this literary work has its characteristics that convey specific goals. Individual social media users have good selfcontrol skills. They will determine their attitude in responding wisely to any comments or trends that apply on social media. Along with the development of this era, the literary world can enter via Instagram to reach closer to its users. An effective mechanism to interact more with customers with social media platforms (Alalwan et al., 2017).

Research on psychological analysis in literary works has increased quite a lot in recent times. The aspects studied were quite diverse from external and internal factors. One of the internal factors that are quite popular is to discuss psychological conditions such as depression, which is a state of frustration, anxiety, helplessness, and hopelessness (Sarfika, 2019). A condition that has a quite fatal impact from depression, namely hopelessness, is the worst point of depression, so that it has been at the end of the depression. The author observes several studies on the analysis of depression in poetry that only see hopelessness as one of the supports in achieving a natural depression as this state of hopeless has not been examined more deeply. As the analysis of representations of depression and suicide in 20th-century poetry, the evolution of literature and similarities between poets can be seen from this research (Otal Torres, 2018). The author also shows emotion and mental stress in Emily Dickinson's poetry to convey ideas illustrating the literary brilliance behind a gloomy, gloomy atmosphere (Jones, 2017). It is also clear that mental suffering is illustrated in Sylvia Plath's poetry, which is analyzed based on Sigmund Freud's psychoanalysis (Thapa, 2020).

This article describes the word or phrase which contains elements of a feeling of hopelessness in psychology. Issues to be discussed related to these elements using the sequence analysis based on intrinsic in the poem such as figurative language consists of comparative, contradictive, relation, and repetition. There are many types of figurative language such as metaphor, simile, symbols, hyperbola, irony, personification, and crocheted analysis of hopelessness feelings (Dancygier \& Sweetser, 2014). Some people were experiencing mental imagery (visual, auditory, and kinetic) when they comprehend verbal metaphors (Carston, 2018).

According to Abramson, hopelessness in attribution theory, which identifies the causes of hopelessness, has three dimensions, namely: 1.) Attribution pattern is a phase of experiencing hopelessness in general. At this stage, the feeling of fear that haunts and is afraid to face the next life after experiencing something traumatic and this feeling will still be felt today. 2.) Negative Consequences The belief in the subject of hopelessness is the loss of 
something meaningful in his life and his inability to live the next day generally as before. 3.) Negative Self Characteristics that in this phase, the hopeless subject can no longer accept all of his circumstances and unable to think and be positive in responding to something at hand (Abramson et al., 2014). This situation is the most severe phase because it can lead to uncontrollable action, the formation of the hopelessness theory is reshaped by forming a causal attribution that consists of three dimensions, namely from 'internal' to 'external,' 'stable' to 'unstable,' and from 'general' to 'specific'. If these three attributes experience adverse events in internal, stable, and general, it can cause depression and hopelessness to become part of it.

With that in poetry, it is necessary to examine its beauty, and many poets make hopelessness a topic conveyed by them. They have their ideas and perspectives about depression which refers to hopelessness. J. C. Dawn, one of the poets who conveyed his work through social media, namely Instagram, has ideas that can convey the feelings of many people about life and hopelessness. Many themes are raised in his writings, such as life, love, women, hope, friendship, and social problems. Sometimes the delivery of the writing can be implicit, but it can be immediately captured by the reader how the writing works. He has a unique idea of addressing hopelessness packed with language that does not even directly reflect that it conveys hopelessness. The language of writing poetry is maximally conveyed and effective to readers (Masruchin, nd). He is so unpredictable because he personifies hopelessness as a natural person and uses parables to describe hopelessness as a vicious insect. The tone of each poem is unique. Some poems reflect joy, while others denote gloom. The author, who calls herself a "traveler soul" knows very well how to convey a situation in a piece of writing that accurately represents feelings. In his second book entitled "Ripple of Existence", there are six sub-chapters: the mystery of existence, wisdom, simplicity, courage, love, and death. Therefore, the writer chose J. C. Dawn's literary work to reveal the second book's hopeless aspect.

\section{Literature Review}

At least three studies focused on psychological analysis in literary works of poetry, which are used as references for this study. Three of these studies take a general perspective of depression, including the first research by Mitchell Jones in 2017 entitled "The Role of Emotional Depression and Mental Duress in the Poetry of Emily Dickinson", the second from (Rahayu, 2018) entitled "Depression in Rupi Kaur's Selected Poems ", and the third (Otal Torres, 2018) entitled" Poetics of Depression: Mental Illness and Suicide in Sylvia Plath and Anne Sexton's Poetry ". (Jones, 2017) Mitchell Jones in his research entitled "The Role of Emotional Depression and Mental Duress in the Poetry of Emily Dickinson" 2017 was unable to analyze it in depth because of the weakness of the research methodology used to explain the contents of the poetry which had been expressed in each language. They are complex and symbolic. Attempts to correlate this with reality without the presence of a specific theory used like the blade of the study have caused the focus of the research to be blurred. Furthermore, trying to complement his previous research, Rahayu adopted Beck's theory of the psychology of depression and succeeded in further explaining the causes and signs of depression in her poetry. However, this research cannot reveal the situation in the real-life context influenced by other dynamic things. It is still limited in the poem's scope, which allows for the absence of any other contexts.

Previous research also contained two that directly discussed aspects of hopelessness in poetry, namely from (Banerjee \& Senapoti, 2018) entitled "An Analytical Study of some of 
the poems of Philip Larkin Based on His Theme of Death" in 2018 revealed in terms of the scope of literature that In fact, it is not enough to explain precisely the context and analysis relationships. Still, in the same literary work, research from (Madlool, 2019) entitled "The Justified Blackness in Larkins Selected Poems" shows that there are quite strong characteristics from his observations through the creative photography method into the poetry, but also causes a lack of analysis from the point of view of the literature work. Both studies use the same author from Philip Larkin that it has been proven in all of his literary works that they have the theme of the dark side of life, so that it does not yet fulfill a broader scope in poetry with similar themes but not dominant.

The Differences lie that this article discusses the shortcomings of existing research to be more specific about the state of hopelessness in J. C. Dawn's poetry by contextualizing the current situation, especially poetry that is still new and the role of the author that significantly influences the reader in conveying a particular situation with a more related situation. The active role of the author in working on social media is also a distinguishing point in this article which will undoubtedly show readers more updates and according to current conditions. In addition to insta poetry through social media, J. C. Dawn wrote a book that deserves to be researched because of its broad reach as well as using Abramson's psychological theory to dissect the meaning of hopelessness in question.

\section{Research Method}

This research is a qualitative descriptive study as a method for analyzing data. The study aims to describe the words that interpret hopelessness in Dawn's poetry. (Setiawan, 2018) argues that describing a phenomenon why or how the event occurred is the goal of descriptive qualitative. In this study, there are two types of data, primary and secondary data. The poems of are the primary data and the secondary data in this study are data related to this issue, topic, and problem. Creswell claims that descriptions can describe people, places, or events in qualitative research (Creswell \& Poth, 2016). The researchers will cite several journals, articles, books to support this research. The first step is to select a poem called "Ripple of Existence" by J. C. Dawn. There are three poems selected from J. C. Dawn to be analyzed in this research entitled Living in A Pride World (poetry 1), Womb (poetry2), and A Soundless Tear (poetry 3). The researchers go through the steps of starting to read the selected J. C. Dawn's poetry. In the second step, the researchers collect the kinds of problems with the sad side of depression and the signs of hopelessness that emerge from Dawn's poems. The researchers analyze the types of sad feelings, and the meaning of the symbols applied in the third step. In the fourth, the researchers use psychological and structural approaches to solve problems. The final step is making conclusions.

\section{Results and Discussion}

\subsection{Original Problem}

The character "I" in the first poem has a bad experience in life. Hatred and feeling drained because of arrogance are shown in the image of "Sometimes I feel drained and lonely." Skepticism with partners is also a pressing situation as this is seen only from one side. The pairs in question are of the opposite forms, such as good and bad, heaven and earth, dark and light. It is as if seeing the world with the same goal, by making comparisons.

Isn't there a purpose greater

Than to see life

With a mind beyond 
The pairs of opposites of which

The world consists?

Bad or good, sin or virtue, defeat or victory

All of these are two ends of

The same thread

In the second poem, the character "I" is in a calm and lonely situation. It is said that in silence, she can find peace. Using similes to express peace is like a wave kissing the shore. However, in a situation that turnS into silence, she does not accept help or anyone else. It has been described as having no inner desire to be interested in life anymore. Stanzas 1-3, picture a sufficient assumption to represent an empty feeling.

The hopelessness aspects here start from within herself. The first internal stanza is indicated by the sentence on the 3rd line of the first stanza, 'pulling into the melody', which means something not finished with oneself. The second stanza is almost the same, and the aspect stage starts from the inner state. While the 1st and 2nd stanzas to the 3rd stanzas are general to specific. The meaning of herself is that her hero is a specific stage with no selfconfidence.

\author{
In Silence \\ I hear the soft, smooth voices \\ of the Universe, \\ pulling me into their melody, \\ consuming me with such \\ peaceful ecstasy. \\ In silence, \\ I hear the roar of rushing thoughts, \\ and yet they are calm \\ as waves kissing the shore. \\ In silence \\ I hear loved ones saying \\ They will never go, \\ But in silence, \\ I see there really is \\ No hand to borrow \\ I am my own hero
}

The problem with the "I" character is that it starts okay but is not good. A collection of boisterous thoughts expressed in simile with explicit disclosure of "as" in the line as waves kissing the shore'. This is supposed to be calm things.

In the third poem the character "she" declares that she has been stolen and has her memory erased because of this condition. The problems in her past are the primary cause because they impact the present life, which no longer dared to move in any direction. Acceptance of oneself by wanting to be in the past is also the beginning of mistrust. The supposition used by the hyperbolic figure in the first verse is as if his life is stolen, which means that bad events areaccidentally lost in life. 


\author{
These past few years, \\ She has been lost to us. \\ Her life's been stolen by a thief \\ who robs her memories, he took them all- \\ words and moments \\ she can't recall. \\ Rigid hands and vacant eyes \\ I feel sadness in her heart. \\ Once she dressed herself, \\ Cut her own food \\ Then dignity dropped away \\ As she sat there helplessly \\ I felt her begging for us \\ To talk to her anyway. \\ She may not respond \\ But she was always there.
}

Some problems are rooted in each character in the three poems above and become the leading cause of helplessness. Situation cues show the depression hypothesis to cause depression style and should be more likely than those who do not attribute any particular negativity when dealing with internal, stable, global factors and significant events, thereby inciting the possibility of becoming discouraged and and depressive symptoms. However, in the presence of a positive life or the absence of adverse events, people exhibiting this style should not be more likely to develop hopelessness and depression than people not exhibiting this style.

\title{
4.2 Unwanted By Oneself
}

Self-acceptance is an individual's capacity to have a favorable view. This cannot be shown by oneself but must be created by other people (Germer et al., 2013). Fear of something is a common thing that everyone can feel. Each individual has specific standards to determine whether he accepts something or even hates it. Resentment or hatred becomes problematic when directed at oneself. In psychological analysis, this is known as self-loathing or self-hate. A person can feel that he is useless, stupid, failed, worthless, and unwanted. These negative emotions are an indication that a person hates himself.

Factors causing a person not to love himself are the demands of life. Individuals only think about the deficiencies that exist in them. Not ambitious enough for themselves, individuals have too high expectations of themselves; successful experiences that are not achieved by themselves.

These characteristics in the first poem lie in the last stanza, showing not wanting by oneself to struggle.

So what does it matter

If we lose

or win? 
Furthermore, the second poem shows that each stanza begins with the word "In silence, "implying that things are difficult to predict in the loneliness and darkness. In the last verse, she has expressed her hopelessness by remaining silent without moving in life again, assuming that resting in the Mother's womb is an option.

In silence.

I rest, curl up

In my Mother's womb.

The expressions of hopelessness in the three poems are clear as the character "I" does not want to continue life but remain living in the past. There is no movement in the present life as all is dark and full of hopelessness.

As she sat there helplessly

I felt her begging for us

To talk to her anyway.

She may not respond

But she was always there.

Likewise, not accepting reality is a form of self-indifference. It is clearly seen in the fourth verse. The character "I" gives a message that all is finished as the roads of hope are closed. She has already dies before the real death comes

For her, death happens

Before she even dies.

I'm not accepting this, but I

Thak her silently for legacy.

When I look at her,

I see the best of me and

The ones who have raised me.

\section{Conclusion}

The conditions experienced by each character in the poems are the stages and causes of hopelessness through different conditions. The first poem, entitled "Living in A Pride World," reveals that the difficult circumstances experienced by the character in the face of the world with the same perspective, simply good or bad, winning or losing, are the stages of attribution patterns and negative consequences. Meanwhile, in the second and third poems, Womb and A Soundless Tear, all stages of hopelessness have been faced, including attribution patterns, negative consequences, and negative self characteristics. The figures of speech have revealed all, and the form of hopelessness experienced is a stage related to the characters in the poems.

\section{References}

Abramson, L. Y., Alloy, L. B., \& Metalsky, G. I. (2014). Hopelessness Depression. In Explanatory Style (pp. 123-144). Routledge.

Abramson, L. Y., Metalsky, G. I., \& Alloy, L. B. (1989). Hopelessness Depression: A TheoryBased Subtype of Depression. Psychological Review, 96(2), 358-372. https://doi.org/10.1037/0033-295X.96.2.358 
Alalwan, A. A., Rana, N. P., Dwivedi, Y. K., \& Algharabat, R. (2017). Social Media in Marketing: A Review and Analysis of the Existing Literature. Telematics and Informatics, 34(7), 1177-1190.

Aras, G. (2015). Personality and Individual Differences: Literature in Psychology-Psychology in Literature. Procedia-Social and Behavioral Sciences, 185, 250-257.

Banerjee, B., \& Senapoti, P. K. (2018). An Analytical Study of Some of the Poems of Philip Larkin Based on his Theme of Death. European Online Journal of Natural and Social Sciences, 7(3), pp-616.

Beck, A. T. (1967). Depression: Clinical, Experimental, and Theoretical Aspects. Hoeber Medical Division, Harper \& Row.

Carston, R. (2018). Figurative Language, Mental Imagery, and Pragmatics. Metaphor and Symbol, 33(3), 198-217.

Chu, X.-W., Fan, C.-Y., Liu, Q.-Q., \& Zhou, Z.-K. (2018). Cyberbullying Victimization and Symptoms of Depression and Anxiety among Chinese Adolescents: Examining Hopelessness as a Mediator and Self-compassion as a Moderator. Computers in Human Behavior, 86, 377-386.

Creswell, J. W., \& Poth, C. N. (2016). Qualitative Inquiry and Research Design: Choosing among Five Approaches. New York: Sage publications.

Dancygier, B., \& Sweetser, E. (2014). Figurative Language. Cambridge: Cambridge University Press.

Germer, C. K., Siegel, R. D., \& Fulton, P. R. (2013). Mindfulness and Psychotherapy. New York: Guilford Press.

Jones, M. (2017). The Role of Emotional Depression and Mental Duress in the Poetry of Emily Dickinson. Student Writing. https://commons.vccs.edu/student_writing/19

Madlool, A. K. (2019). The Justified Blackness in Larkins Selected Poems. College of Education for Women Journal, 10/3.

Masruchin, U. N. (n.d.). Buku Pintar Majas, Pantun, dan Puisi. Jakarta: Penerbit Nauli Media.

Minderop, A. (2010). Psikologi Sastra: Karya, Metode, Teori, dan Contoh Kasus. Jakarta: Yayasan Pustaka Obor Indonesia.

Otal Torres, A. (2018). Poetics of Depression: Mental Illness and Suicide in Sylvia Plath and Anne Sexton's Poetry. http://diposit.ub.edu/dspace/handle/2445/123542

Rahayu, S. D. (2018). Depression in Rupi Kaur's Selected Poems [PhD Thesis]. Malang: Universitas Islam Negeri Maulana Malik Ibrahim.

Rahman, I. A. (2021). Metaphor Analysis on Students' English Poems. English Language in Focus (ELIF), 1(1), 1-8.

Rahmi, Y., Chaesar, A. S. S., \& Kusyani, D. (2017). Peran Media Sosial Terhadap Sastra: Kajian Hegemoni. Yogyakarta: Universitas Negeri Yogyakarta.

Saputra, A. D. (2011). Perempuan Subaltern dalam Karya Sastra Indonesia Poskolonial. LITERASI: Indonesian Journal of Humanities, 1(1), 16-30.

Sarfika, R. (2019). Hubungan Keputusasaan dengan Depresi pada Pasien Diabetes Melitus di Padang. NERS Jurnal Keperawatan, 15(1), 14-24.

Setiawan, A. A., Johan. (2018). Metodologi penelitian kualitatif. Jakarta: Jejak (Jejak Publisher).

Thapa, B. (2020). Anguished Psyche is Selected Poems of Sylvia Plath [Thesis]. http://202.45.147.228:8080/handle/123456789/17 